\title{
Achievements and perspectives in cloned and transgenic cattle production by nuclear transfer: influence of cell type, epigenetic status and new technology
}

\author{
Alinne Gloria Curcio ${ }^{1,4}$, Fabiana Fernandes Bressan ${ }^{2,3}$, Flávio Vieira Meirelles ${ }^{2,3}$, Angelo José Burla Dias ${ }^{1}$ \\ ${ }^{1}$ Laboratório de Reprodução e Melhoramento Genético Animal, Centro de Ciências e Tecnologias Agropecuárias, Universidade \\ Estadual do Norte Fluminense Darcy Ribeiro (UENF), Campos dos Goytacazes, RJ, Brasil. \\ ${ }^{2}$ Departamento de Medicina Veterinária, Faculdade de Zootecnia e Engenharia Alimentar (FZEA), Universidade de São Paulo \\ (USP), Pirassununga, SP, Brasil. \\ ${ }^{3}$ Departamento de Cirurgia, Faculdade de Medicina Veterinária e Zootecnia (FMVZ), Universidade de São Paulo (USP), São \\ Paulo, SP, Brasil.
}

\begin{abstract}
Genetically modified cattle production is motivated by many factors, including recombinant protein production for therapeutic purposes, disease models and animals presenting improved production traits. Nuclear transfer (NT), combined with efficient cultivation methods, genetic modification and donor cell selection is important for transgenic cattle production. Studies have found that adult cells (such as fibroblasts and cumulus cells, among others) used as nuclear donors achieved results similar to those of fetal cells, with the advantages of easier collection and a known genotype/phenotype. However, no consensus has been reached on the influence of cell type on transgene expression levels and post-reprogramming capacity after nuclear transfer, and these factors appear to be related to epigenetic factors. The development of new strategies, such as chromatin-modifying agents (CMAs), in vitro generation of induced pluripotent cells (iPS cells) and precise genome editing techniques are being explored and may influence nuclear reprogramming success for efficiently producing genetically modified bovine clones.
\end{abstract}

Keywords: bovine, cloning, epigenetic, nuclear reprogramming, transgenesis.

\section{Introduction}

Commercial and scientific interest in transgenic animal production has grown worldwide. This is due to the possibility of using animals to produce recombinant proteins for therapeutic purposes (An et al., 2012), develop in vivo gene function models to study organogenesis and development (Berg et al., 2011), understand important diseases and produce animals with improved production characteristics $(\mathrm{Wu}$ et al., 2015).

DNA pronuclear injection was the first and most common method for producing transgenic animal for years, but low transgenesis rates limited its use. Murakami et al. (1999) reported that only $2.9 \%$ of bovine embryos produced after DNA pronuclear injections were genetically modified, and $70.3 \%$ of those were chimeras. This is due to the random insertion of exogenous DNA into the host cell genome (Murakami et al., 1999).
Establishing nuclear transfer (NT) (Wilmut et al., 1997) in conjunction with cell culturing and efficient genetic modification methods provides new strategies for producing transgenic livestock due to the possibility of selecting cells prior their use as a nucleus donor, ensuring a transgenesis efficiency of near $100 \%$.

Initially, nuclear reprogramming by NT was reported possible using embryonic cells (blastomeres) as nuclear donors for both laboratory and farm animals (Illmensee and Hoppe, 1981; Willadsen, 1986), and it was believed that pluripotent cells were responsible for nuclear reprogramming success and proper embryo development (McGrath and Solter, 1983; Prather et al., 1987). This technique limited livestock production because deriving and maintaining embryonic stem cell (ES) cultures in vitro is not possible as pluripotent cells cultured in vitro are not yet fully characterized or reproducible in domestic animals (Brevini et al., 2008; Nowak-Imialek et al., 2011). The birth of the first farm animal from nuclear transfer using in vitro cultured fetal cell lines was reported in 1996 (Campbell et al., 1996), and the birth of Dolly "the sheep" (Wilmut et al., 1997) revolutionized the reprogramming concept at that time by demonstrating that differentiated adult somatic cells could be nuclear donors to produce cloned animals.

A short time after Dolly's achievement, Schnieke et al. 1997, demonstrated the first use of NT to produce the first transgenic animal. They produced a transgenic sheep that secreted factor IX in its milk (Schnieke et al., 1997). Thereafter, other cell types have been used to clone and produce transgenic embryos with different transgene incorporation efficiency rates (Arat et al., 2001; Feng et al., 2015; Gong et al., 2004).

Recently developed precise techniques for genome editing have enhanced the safety and efficiency of producing transgenic farm animals desirable in both agriculture and biomedicine (Petersen and Niemann, 2015; Rémy et al., 2010). TALENs (transcription activator-like effector nucleases) technology has allowed genetic modification to become more precise and less time-consuming. More recently, CRISPR technology revolutionized the animal transgenic field, bringing several advantages such as more precise targeting, fewer off-targets, and faster technology (Carlson et al., 2012; Menchaca et al., 2016; Lotti et al., 2017). It is important to highlight, however, that efficient TALEN or CRISPR technology protocols for producing transgenic farm animals rely on NT 
procedures to assure high efficiency in terms of transgenic offspring birth. Therefore, evaluating the cell phenotype for the precise genetic modification to be performed remains a concern.

Although NT uses different cells types, the influence of the cellular differentiation stage on both cloning and transgene integration efficiency are of interest. This relationship is not well-defined, and more studies are needed to fully understand it; however, it is clear that epigenetic factors are involved, affecting primarily post-nuclear transfer reprogramming efficiency (Smith et al., 2012, 2015).

This review (i) presents a brief history of the cell types used in cloning and transgenic cattle production, (ii) addresses the epigenetic issues that may affect transgenic and cloning cattle production efficiency and (iii) describes current strategies, such as chromatinmodifying agents (CMA), iPS cells and endonucleases as means to innovate and improve results.

\section{Use of somatic cells by nuclear transfer in transgenic cattle production}

The term "transgenic" refers to an organism whose genome was permanently altered by insertion, modification or inactivation of DNA, with the genetic modification being transmitted to its offspring (Rülicke et al., 2007). In livestock production, transgenic animals have been developed primarily for use as bioreactors to produce high quality medicinal proteins on a large scale, with lower costs and higher efficiency compared to other production methods such as bacterial, yeast and cells culturing (Houdebine, 2009; Bagle et al., 2012).

NT is the most common method for transgenic cattle production (Jeong et al., 2016; Lu et al., 2016; Ren et al., 2017; Gao et al., 2017;). This is primarily due to the possibility of identifying the transgene in the cell genome before using it as a nuclear donor, which may avoid chimera production, genetic anomalies in the offspring, homogenous offspring production or an unintentional knock-out due to transgene localization in the non-coding DNA (Bressan et al., 2008, 2011).

The NT technique fuses one diploid cell (embryonic, fetal or adult), with an enucleated oocyte (recipient cytoplast) and is chemically activated to trigger embryo development. Thus, the recipient oocyte must induce nuclear reprogramming and support embryonic development, while the donor cell nucleus must be totipotent (Wilmut et al., 2015)

Many cell types and culture and manipulation conditions (presence or absence of bovine fetal serum, cell passage number, oxygen tension and others) have been studied for their effects on transgene expression levels in the donor cell nucleus and the cloned calves (Cho et al., 2004; Gong et al., 2004; He et al., 2016). As previously discussed, initial studies used embryonic stem cells from embryos in the morula or blastocyst stage for their ability to generate any embryonic tissue (Puri and Nagy, 2012). In mice, embryonic stem cells efficiently produce genetically modified individuals, but their use in producing transgenic farm animals is challenging as was previously described regarding ES cells from domestic animals (Blomberg and Telugu, 2012; Gandolfi et al., 2012). A brief summary of important NT achievements is shown in Figure 1.

After the NT of a differentiated adult cell (mammary gland cell) to an enucleated oocyte, the birth of Dolly the sheep in 1996 confirmed speculation that even after having reached a certain stage of differentiation, differentiated somatic cells could be reprogrammed if aided by a cytoplasmic apparatus (Wilmut et al., 1997).

Therefore, the possibility of using others cell types was investigated for producing both clones and transgenic cattle by NT. In 1998, Kato et al., reported the birth of eight heifers produced by nuclear transfer using cumulus cells and oviduct epithelial cells from an adult animal (Kato et al., 1998). In 2000, the same group compared clone production efficiency using adult female cells (cumulus, oviduct and uterine cells) and ear and skin cells from neonates and adult male cattle. These authors observed that clones from adult cells often died in the final stages of gestation, and those that survived often had abnormalities (Kato et al., 2000). The authors attributed these findings to donor cell mutations and telomere shortening, factors that could occur in aging animals. Today, it is known that these modifications are also caused by epigenetic failures in donor cell reprogramming (Yang et al., 2007; Song et al., 2014).

Arat et al. (2001) demonstrated the first use of adult cells (granulosa cells) for transgenic embryo production in cattle. Cho et al. (2004) reported that the embryo development rate post nuclear transfer, as assessed by green fluorescent protein (GFP) expression, was greater when smaller cumulus cells from early passages were used compared to adult and fetal fibroblasts. According to the authors, using small cumulus cells allows for better nucleus-cytoplasmic interaction in the recipient cytoplast. Moreover, when NT is performed with metaphase II oocytes, synchronized cells in the G0/G1 phase of the cell cycle (smaller cells) are more effective in embryonic development (Campbell, 1999). Concerning passage number, prolonged culturing periods can potentially result in genetic alterations. Genetic alteration is a major factor in cloned and transgenic production. It is not fully understood; however, interestingly, embryos resulting from NT failed to express some genes related to nuclear reprogramming (e.g., Oct-4 gene) and placentation (Yang et al., 2007).

Higher production rates of transgenic bovine blastocysts were also obtained using cumulus (44.6\%) and oviduct fetal epithelial cells (49.1\%) than with fetal fibroblasts (32.7\%) (Gong et al., 2004). This indicates that adult cells can efficiently produce transgenic cattle. In some situations, adult cells may be more suitable than embryonic or fetal cells due to easier collection and knowing the genotype/phenotype. 


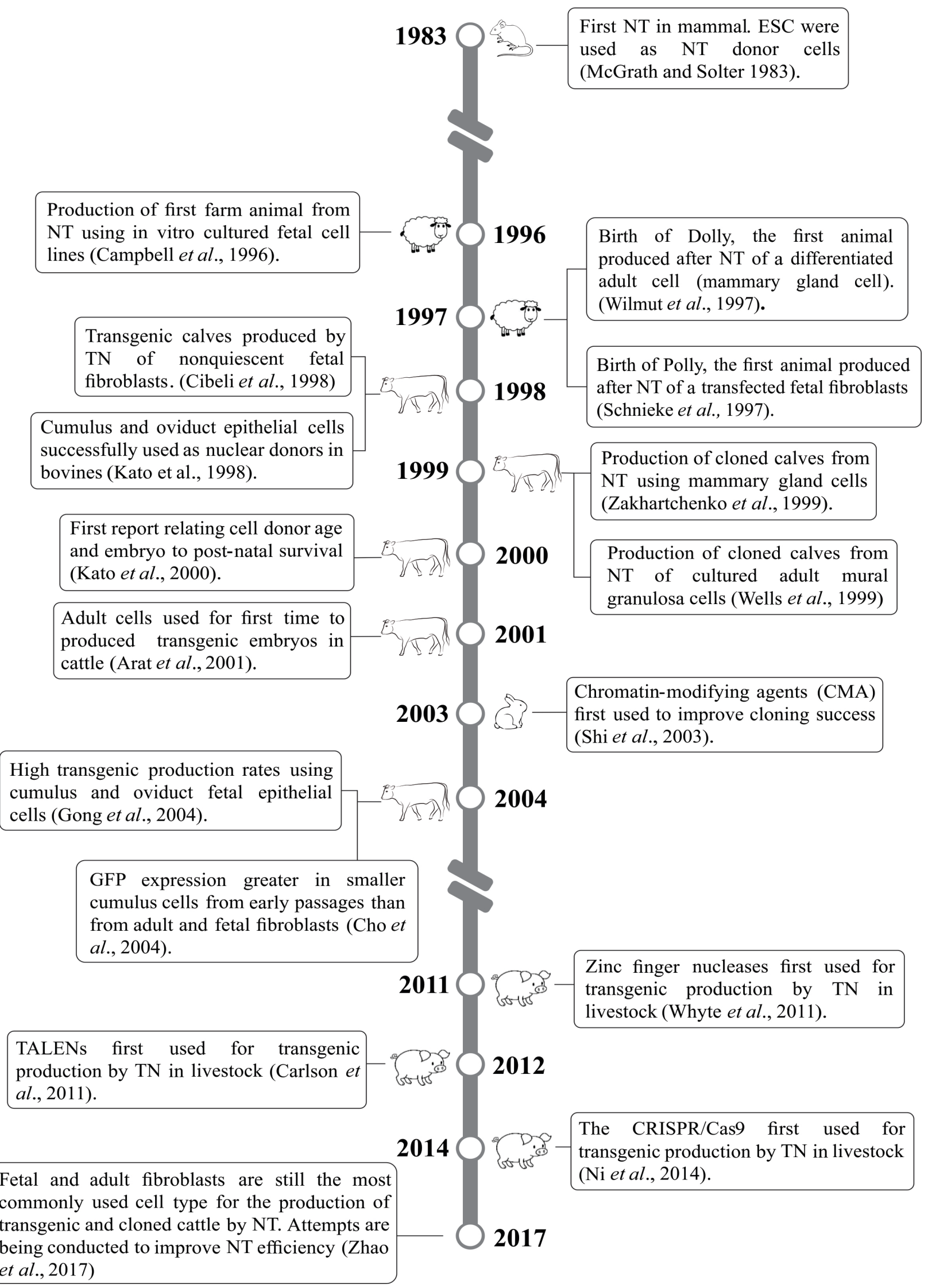

Figure 1. Timetable of a brief summary of important NT achievements. 
In 2006, Sung et al. tested hematopoietic mouse cells at different differentiation stages (hematopoietic stem cells (HSC), progenitor cells and granulocytes) and found that cloning efficiency increases with the donor cell's differentiation state, and granulocytes were the best cell type for cloning. The authors concluded that hematopoietic cells appeared to be an exception to the hypothesis that "undifferentiated cells are more efficient than differentiated somatic cells for cloning production". Inoue et al. (2006) demonstrated that cloned embryos derived from HSC failed to express five of the six important embryonic genes examined, including Hdacl (encodes histone deacetylase 1), a key zygotic gene activation regulator. These results were attributed to less plasticity of hematopoietic stem cells (Inoue et al., 2006).

Mammary gland epithelial cell use in transgenic animal production has grown due to its applicability (Zhan et al., 2017). Regarding recombinant protein production, Feng et al. (2015) used mammary gland cells to produce transgenic sheep expressing the alpha-lactoferrin gene. After transfection with plasmid encoding alpha-lactoferrin, cells secreted recombinant protein at detectable levels in the culture media. Similarly, our group reported generating live offspring after donor cell NT from developing mammary glands in cattle. We described constructing specific vectors to encode the B-casein promoter and the hFIX gene, as well as integrating them into cattle donor cells and generating offspring (Monzani et al., 2011, 2013). This improvement represents another effective method for selecting cells prior to their use as nuclear donors and analyzing tissue-specific promoter activity.

Fetal and adult fibroblasts remain the most common cell type for producing transgenic cattle by NT. This may be due to the ease of collection and in vitro culturing and that the cells divide several times before reaching senescence. In theory, different cell types could be used to produce clones and transgenic animals by NT with different success rates, but nuclear reprogramming efficiency appears to be related to donor cell nucleus plasticity and the capacity to undergo nuclear programming before NT. The role of the nucleus donor cell's epigenetic status on reprogramming efficiency is thus gaining interest, and this relationship will be further discussed below.

\section{Epigenetic factors related to animal production}

Epigenetic modifications are heritable changes in DNA structure and organization that are unrelated to changes in the nucleotide base sequence. The term was first proposed to explain how cells carrying identical DNA could express different genes (García et al., 2012).

This concept is now well-recognized, and these modifications occur through changes in the chromatin that alter gene transcriptional activity; however, the effect of these alterations remains unclear. Herein we will focus on epigenetic modifications that primarily occur by two distinct mechanisms: (i) histone modification and (ii) cytosine methylation in $\mathrm{CpG}$ islands in double-stranded DNA (Cheng and Blumenthal, 2010; Reik et al., 2001).
Changes in the chromatin, such as methylation and histone modifications, are highly correlated and alter gene transcriptional activity by leaving chromatin exposed or protected from transcription machinery (Cheng and Blumenthal, 2010).

DNA is a long molecule that must be packaged for nuclear containment. Thus, the chromatin is wrapped around a histone octamer, constituting the nucleosome, the DNA's basic organizational unit. Histones are proteins with a carboxy-terminal domain and amino-terminal tail where epigenetic modifications occur. The main histone modifications include methylation of lysine and arginine residues, acetylation of lysine residues, and ubiquitination, sumoylation and phosphorylation of serine and threonine residues. Of these, lysine residue acetylation and methylation are the most well-known and studied (García et al., 2012).

Histone acetyltransferase (HAT) and histone deacetylase (HDAC) are the enzymes that control histone acetylation levels. Histone hyperacetylation is associated with chromatin regions with high transcriptional activity, while hypoacetylation is found in low activity regions (Schmittwolf et al., 2005). Histone methylation may be related to non-transcribed or transcribed regions, depending on which residue is methylated. For example, histone $\mathrm{H} 3$ lysine residue 9 methylation ( $\mathrm{H} 3 \mathrm{~K} 9 \mathrm{me})$ and histone $\mathrm{H} 3$ lysine residue 27 methylation (H3K27me) are related to nontranscribed regions, while histone $\mathrm{H} 3$ lysine residue 4 (H3K4me), 36 (H3K36me) and 79 (H3K79me) methylation are related to transcribed regions. These events are controlled by histone methyltransferase enzyme (HMTs).

DNA $\mathrm{CpG}$ island methylation is a primary epigenetic mechanism that directly affects gene expression as some transcription factors only bind to unmethylated DNA sequences; thus, methylation may induce gene sequence expression loss (Salozhin et al., 2005). Methyltransferases are enzymes that control DNA methylation levels. DNA (cytosine-5)methyltransferase 1 (DNMT1) maintains methylation levels during DNA replication. DNMT2 is related to RNA methylation to enhance tRNA stability, and DNMT3A and DNMT3B are responsible for de novo methylation (Iager et al., 2008).

Proper DNA methylation reprogramming is essential during gametogenesis and early embryogenesis to generate healthy offspring; therefore, its disruption or incomplete reprogramming may directly affect other processes such as NT. Male and female gametes have a hypermethylated genome due to gametogenesis, and after fertilization, the pro-nuclei undergo a process called "demethylation". In the male pro-nucleus, this is a fast and active process, whereas in females, it occurs slowly and progressively (Yang et al., 2007). At the 816 cell stage of concurrent embryonic genome activation, epigenetic parameter reprogramming occurs, known as de novo methylation. These processes are usually coordinated, culminating in successful embryo implantation and embryonic and fetal development. During early embryonic development and cell differentiation, epigenetic markers are gradually 
established, forming different heritable epigenetic patterns that are important for maintaining the identity of differentiated cells (Schmittwolf et al., 2005).

In nuclear transfer, nuclear reprogramming involves two complex epigenetic steps: (i) dedifferentiation of a differentiated somatic cell to a totipotent stage by epigenetic marker removal in the donor nucleus and (ii) redifferentiation of totipotent embryonic cells into all tissue types of a new animal (Yang et al., 2007). Such events occur quickly, whereas in naturally fertilized embryos, such epigenetic markers are established during gametogenesis and fertilization, and thus may diminish NT efficiency.

Despite current efforts and findings in this field, embryo production by NT remains low at approximately $1-5 \%$, and embryos derived from NT typically present implantation failures, fetal abnormalities, and gestational, placentation and calving problems. Many of these abnormalities are due to nuclear reprogramming failure, caused by changes in histone parameters, DNA methylation and gene expression related to early embryogenesis and placentation (Bressan et al., 2009; Smith et al., 2015; Suzuki et al., 2009; Yang et al., 2007).

Several studies report that the more advanced the developmental stage of the nuclear donor cell, the lower the efficiency of the embryo production by NT. In mice, for example, reduced clone production occurs when blastomeres at a more advanced developmental stage are used as donor cells (22\% - 2 cells, $14 \%$ - 4 cells and $8 \%$ 8 cells). In cattle, NT blastocyst production rates were reported at $28 \%$ when blastomeres were used as nuclear donors. When fetal and adult fibroblasts were used, efficiency was significantly reduced $(13 \%$ and $5 \%$, respectively) (Wilmut et al., 2002).

Blelloch et al. (2006) demonstrated that stem cell production efficiency in mice was higher when neural stem cells were used as NT donors compared to differentiated neuronal cells. They also demonstrated that hypomethylation of differentiated cell genomes increased clone production (Blelloch et al., 2006).
Matoba et al. (2014) identified mouse reprogramming resistant regions (RRRs) that were wellexpressed in 2-cell in vitro fertilized embryos, but not in cloned embryos. These RRRs are enriched for H3K9me3 (trimethylation of histone $\mathrm{H} 3$ on lysine residue $9 \mathrm{H} 3 \mathrm{~K} 9 \mathrm{me} 3$ ) on the donor cell genome. According to these authors, this region is a major barrier to efficient nuclear reprogramming in mice and its removal by ectopically expressed H3K9me3 demethylase, Kdm4d, significantly improved SCNT efficiency (Matoba et al., 2014).

Thus, more recent approaches have focused on the possibility that open chromatin configurations (already found in stem cells, embryonic and fetal cells) could benefit nuclear reprogramming (Song et al., 2014). Because the use of embryonic stem cells in farm animals is still incipient, new strategies have been developed to optimize clones and transgenic animals produced by NT. Among these strategies, using chromatin-modifying agents (CMAs) in donor cells prior to NT, as well as the possibility for using non-embryonic but pluripotent stem cells (the induced pluripotent stem cells or iPS cells) as donor cells have shown significant potential and are further discussed herein.

\section{Modeling cellular epigenetic status for nuclear transfer}

Due to growing evidence of epigenetic reprogramming failures in NT embryos, chromatinmodifying agents (CMAs) are being studied in several species such as cattle, sheep, buffalo, mice, swine and rabbits (Cervera et al., 2009; Hu et al., 2012; Iager et al., 2008; Kishigami et al., 2006; Luo et al., 2013; Shi et al., 2008). CMAs are chemical substances that change cellular epigenetic patterns. Trichostatin A (Kishigami et al., 2006), sodium butyrate (NaB) (Shi et al., 2003), mcarboxycinnamic acid bishydroxamide (CBHA) (Song et al., 2014), Scriptaid (Wang et al., 2011) and valproic acid (Xu et al., 2012) are examples of substances used for NT procedures, as shown in Figure 2.

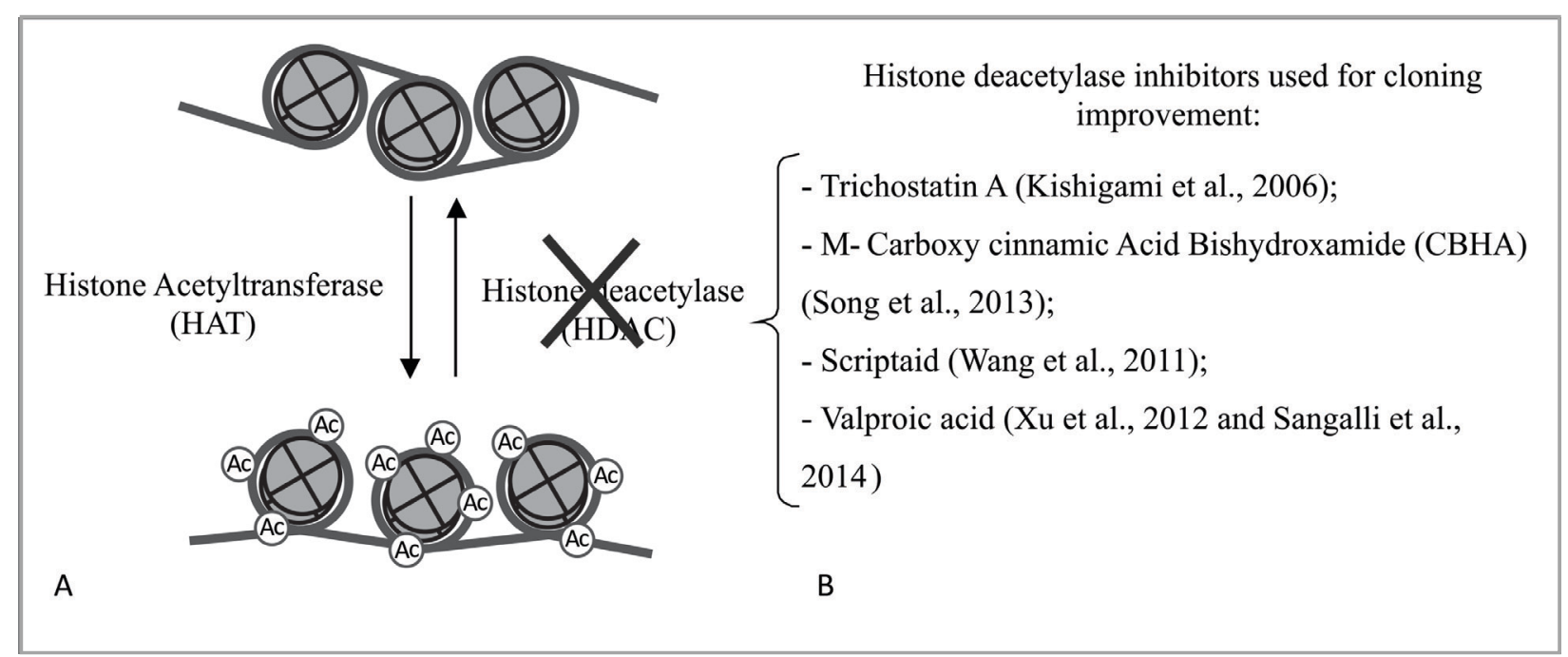

Figure 2. (A) Schematic drawing of histone acetyltransferase and histone deacetylase activity. Note that using histone deacetylase inhibitors may improve histone acetylation levels, which could increase chromatin exposure to transcription machinery. (B) Examples of histone deacetylase inhibitors. 
In cattle, use of trichostatin A (TSA), a histone deacetylase inhibitor, led to production of 8-cell cloned bovine embryos with histone $\mathrm{H} 4$ acetylation levels at lysine 5 (H4K5ac) similar to their fertilized counterparts and significantly greater than the control group. This treatment has also improved in vitro embryo production, reaching levels close to those of in vitro fertilization (IVF) embryos (Iager et al., 2008). According to Kong et al. (2014), TSA also increases telomere length and may be a mechanism by which this substance improves cloned embryo development (Kong et al., 2014).

In 2003, Shi et al. analyzed the effect of treating nucleus donor cells with different chromatinmodifying agents: Trichostatin A; 5-aza-2deoxycytidine (Aza-C, DNA methylation inhibitor); 5bromodeoxyuridine; and sodium butyrate $(\mathrm{NaB})$ on embryo development. Interestingly, $\mathrm{NaB}$, another histone deacetylase inhibitor, improved the proportion of cloned embryos that developed to blastocyst stage $(59 \%)$ compared to the untreated group (26\%) (Shi et al., 2003).

In swine, the use of CBHA increased blastocyst formation as well as the levels of histone 3 acetylation at residue 9 (H3K9ac) and residue 18 (H3K18ac) and histone 4 at residue 16 (H4K16c). It also increased development-related gene expression, such as POU5F1, CDX2 and the imprinted IGF2 gene (Song et al., 2014).

Valproic acid (VPA) is a fatty acid used to treat central nervous system diseases. Studies have shown it induces differentiated cell reprogramming. In miniature pigs, embryos treated with VPA showed enhanced Oct$3 / 4$ expression and in vitro development after cell nuclear transfer (Miyoshi et al., 2010). In bovines, Xu et al. (2012) tested different VPA concentrations at different time periods for activation. They found that 4 $\mathrm{nM}$ of VPA over 24 hours increased cleavage and blastocyst rates, reduced apoptosis in blastocysts and improved immunofluorescent signals for $\mathrm{H} 3 \mathrm{~K} 9 \mathrm{ac}$ in a pattern similar to that of in vitro fertilized (IVF) embryos (Xu et al., 2012).

Using scriptaid 14 hours after activation increased NT bovine embryo production in vitro and immunofluorescent signals for $\mathrm{H} 3 \mathrm{~K} 9 \mathrm{ac}$, decreased fluorescent signals for $\mathrm{H} 3 \mathrm{~K} 9 \mathrm{~m} 2$ in all analyzed embryonic stages (two-cell, eight-cell, and blastocyst stages) and increased expression levels of two developmentally important genes, Interferon tau (IFN-t) and Oct4 (Wang et al., 2011). A recent work also demonstrated that Scriptaid increased in vitro development of NT mini-pig embryos and improved acetylation levels on $\mathrm{H} 3 \mathrm{~K} 14$ and development-related gene expression (AKT, Oct4 and PGC-1 $\alpha$ ) (Zhang et al., 2017).

Interestingly, less than twenty genes are typically deregulated in these embryos, and it is important to identify which gene networks are disrupted (Beyhan et al., 2007). A recent microarray study used Trichostatin $\mathrm{A}$ to evaluate the effects of assisted epigenetic modification of NT bovine blastocyst transcriptional profiles. Despite TSA treatment (TSANT) and improved epigenetic reprogramming parameters, in vitro embryonic development yield and quality compared to the untreated control (CTR-NT) revealed few genes were differentially expressed in TSA-NT embryos $(1907=5.1 \%$ versus CTR-NT $4.3 \%)$. According to the authors, this suggests that the imperfect expression of a few genes can result in a defective phenotype due to a ripple effect, which is not completely responsive to TSA treatment (Hosseini et al., 2016).

Although much has been reported on cloned embryo production, minimal and controversial data are available regarding the offspring, especially from domestic animals. Our group has studied whether CMAs targeting chromatin acetylation and DNA methylation can alter chromatin configuration to improve nuclear reprogramming and enhance offspring results. Thus, bovine fibroblasts were treated with either 5-aza-2'-deoxycytidine (AZA) plus trichostatin (TSA), hydralazine (HH) plus valproic acid (VPA) or VPA alone and used as NT donor cells. Cloned bovine zygotes were also treated with TSA to test whether the effect would be more pronounced in cells or embryos. Although live offspring were born from both the control and treated groups, no evidence that either nuclear donor cells or cloned zygotes with CMAs positively affected pre- and post-implantation development of cloned cattle (Sangalli et al., 2012, 2014). Thus, more studies are needed to identify potentially important deregulated bovine genes to find strategies to correct their expression and to identify possible targets of disrupted maternal recognition before the embryos are transferred to recipients.

\section{iPS cell use for cloned animal production by nuclear transfer}

iPS cells are adult cells that have been genetically induced into a pluripotent state similar to embryonic stem cell stages by introducing the specific genes, Oct4, Sox2, KLF4 and C-MYC, known as OSKM factors (Takahashi and Yamanaka, 2006; Takahashi et $a l ., 2007)$. The role of other factors, such as Nanog, Lin28, TCL-1A, has also been evaluated (Yu et al., 2007; Picanço-Castro et al., 2011).

iPS cells are a new type of pluripotent stem cell that are highly proliferative and can form different tissues. iPS cells are similar to embryonic stem cells in morphology, pluripotent gene expression, promoter methylation level, teratoma formation capacity and ability to differentiate into all cell types (Cao et al., 2012).

In vitro pluripotent cell production technology plays an important and unique role in animal production because "true" stem cells cannot be efficiently produced or maintained in vitro, as previously discussed (Muñoz et al., 2008; Nowak-Imialek et al., 2011). Conversely, iPS cells have already been reported in several species, including both domestic (e.g., cattle, dog, sheep, swine, horses) and endangered animals (e.g., felids) (Gonçalves et al., 2014; Koh and Piedrahita, 2014; Ezashi et al., 2016).

iPS cells, as well as embryonic stem cells, allow accurate genetic manipulation (Park and Telugu, 
2014). In cattle, their use accelerates improvement of desirable genetic traits in livestock, which has been the aim of different research groups (Cao et al., 2012). Recently, studies using iPS cells as donor nuclei for NT have been reported in mice (Zhou et al., 2010; Liu et al., 2012) and swine (Cheng et al., 2012). Although these studies have reported that cloned embryos were generated after NT using iPS cells, no major improvement on embryo production was reported until now. Therefore, despite the advances that combining these two biotechniques may bring to the reproductive and biomedical fields, more solid and reliable studies are soon expected.

\section{Perspectives in animal transgenesis and conclusions}

Efforts are underway in the cloning and transgenesis fields, as the efficiency of the animals that are born remains low. The use of transgenic iPS cells to enhance $\mathrm{TN}$ efficiency is promising but has not currently been tested or validated on a large scale. The use of CMAs, however largely studied, still presents controversial results regarding its efficiency in improving offspring number and health. However, transgenesis techniques have evolved into safer and simpler techniques. Thus, endonucleases appear to have a key role in facilitating mammalian genome engineering.

Endonucleases are restriction enzymes that cleave DNA in a specific manner. Meganucleases, zinc finger nucleases (ZFNs) and transcription activator-life effector nucleases (TALENs) were the first three classes of customizable DNA-binding proteins developed, but their low-specificity limits their use (Peng et al., 2016).

Recently, a defense system against foreign nucleic acids, such as viruses or plasmids, initially described in prokaryotes, has been used to improve transgene efficiency (Mojica et al., 2000). The CRISPR (clustered regulatory interspaced short palindromic repeats) technology uses repeated short sequences interspaced by non-transcribed regions (spacers) that are closely associated with gene regions (CRISPR associated genes - Cas) that codify nucleases, polymerases and helicases, which are fundamental to the system's function (Jansen et al., 2002).

Therefore the CRISPR-Cas 9 system is a powerful, precise and relatively simple tool developed for gene editing, based on the bacterial CRISPR-Cas defense system (Jinek et al., 2012; Cong et al., 2013). The technique refers to RNA guides (CRISPR) that orient the endonuclease, Cas 9, to cleave the DNA sequence in a specific manner. Using CRISPR-Cas 9 makes it possible to introduce a sequence of exogenous DNA (knock-in) at a specific site to prevent deleterious effects from random integration into the genome, which is important for transgenic animal production (Hsu et al., 2014).

A recent study produced cattle with increased resistance to tuberculosis, by inserting natural resistance-associated macrophage protein-1 (NRAMP1), using the single Cas9 nickase (Cas9n)-mediated singlestrand break (SSB) for the first time, with the potential to generate a non-homologous end-joining (NHEJ) repair pathway. This technique reduced off-target effects and both transgenic bovine fetal fibroblasts and cattle were efficiently produced (Gao et al., 2017). Bevacqua et al. (2016) reported using the CRISPR/Cas9 system to induce knockout and knock-in alleles of the bovine PRNP gene responsible for mad cow disease, both in bovine fetal fibroblasts and in IVF embryos (Bevacqua et al., 2016).

The CRISPR-Cas 9 system has also been used to produce knockout genes. Choi et al. (2015) reported disrupting chromosomally integrated exogenous eGFP genes using an RNA-guided endonuclease in bovine transgenic somatic cells. The fibroblasts were efficiently used for NT and developed in the blastocyst stage. This system may also be used for DNA labeling, regulating gene expression, RNA cleavage, gene mapping and RNA screening (Hale et al., 2009; Choi et al., 2015; Deng et al., 2015). Recently, Jeong et al. (2016) reported the first production of pharmaceutical products in cattle using the CRISPR-Cas9 system. They produced human fibroblast growth factor 2 (FGF2) transgenic fibroblasts using CRISPR-Cas9-mediated homologous recombination. According to the authors, FGF2 was secreted in culture medium and when used as a nucleus donor in NT, the blastocysts produced were also transgenic (Jeong et al., 2016).

In brief, precise genome editing technologies are widely used in cattle and other domestic animals to improve transgenesis (Menchaca et al., 2016; Niu et al., 2017; Wu et al., 2017), and most of these studies rely on TN technology to produce live offspring. It is possible that the knowledge gained through the CRISPR-Cas 9 system may soon be used in cloning production. The system should be used to identify genes that do not work well after nuclear reprogramming and to correct the problems associated with the SCNT technique.

In conclusion, (i) different cell types can theoretically be used for cloning and transgenic production with different rates of nuclear reprogramming success and transgene incorporation. (ii) Nuclear reprogramming efficiency appears to be closely related to the differentiation stage of the donor cell nucleus, and its success rate is higher when using less differentiated cells in SCNT, such as stem and fetal cells. (iii) These results are likely due to epigenetic marks, and (iv) studies on CMAs and iPS cells have shown promising results in this field. Finally, (v) the use of RNA-guided endonucleases should improve transgene expression in offspring. The knowledge gained in this field could be used to improve nuclear transfer efficiency.

\section{Acknowledgments}

FAPERJ grant $112.123 / 2012$ and FAPESP grant 2015/26818-5.

\section{References}

An LY, Yuan YG, Yu BL, Yang TJ, Cheng Y. 2012. 
Generation of human lactoferrin transgenic cloned goats using donor cells with dual markers and a modified selection procedure. Theriogenology, 78:1303-1311.

Arat S, Rzucidlo SJ, Gibbons J, Miyoshi K, Stice SL. 2001. Production of transgenic bovine embryos by transfer of transfected granulosa cells into enucleated oocytes. Mol Reprod Dev, 60:20-26.

Bagle TR, Kunkulol RR, Baig MS, More SY. 2012. Transgenic animals and their application in medicine. Int J Med Res Health Sci, 2:107-116.

Berg DK, Smith CS, Pearton DJ, Wells, DN, Broadhurst R, Donnison M, Pfeffer PL. 2011. Trophectoderm Lineage Determination in Cattle. Developmental Cell, 20:244-255.

Bevacqua RJ, Fernandez-Martín R, Savy V, Canel NG, Gismondi MI, Kues WA, Carlson DF, Fahrenkrug SC, Niemann H, Taboga OA, Ferraris S, Salamone DF. 2016. Efficient edition of the bovine PRNP prion gene in somatic cells and IVF embryos using the CRISPR/Cas9 system. Theriogenology, 86:1886-1896.

Beyhan Z, Ross PJ, Iager AE, Kocabas AM, Cunniff K, Rosa GJ, Cibelli JB. 2007. Transcriptional reprogramming of somatic cell nuclei during preimplantation development of cloned bovine embryos. Dev Biol, 15:637-49.

Blelloch R, Wang Z, Meissner A, Pollard S, Smith A, Jaenisch R. 2006. Reprogramming efficiency following somatic cell nuclear transfer is influenced by the differentiation and methylation state of the donor nucleus. Stem Cells, 24:2007-2013.

Blomberg L, Telugu B. 2012. Twenty Years of Embryonic Stem Cell Research in Farm Animals. Reprod Domest Anim, 47:80-85.

Bressan FF, De Bem, THC, Perecin F, Lopes FL, Ambrosio CE, Meirelles FV, Miglino MA. 2009. Unearthing the roles of imprinted genes in the placenta. Placenta, 30: 823-834.

Bressan FF, Miranda M Dos S, De Bem THC, Pereira FTVM, Binelli M, Meirelles FV. 2008. Production of transgenic animals by nuclear transfer: model for biological studies. Rev Bras Reprod Anim, 32:240-250.

Bressan FF, Perecin F, Sangalli JR, Meirelles FV. 2011. Reprogramming somatic cells: pluripotency through gene induction and nuclear transfer. Act Sci Vet, 39(Suppl 1):83-95.

Brevini TAL, Antonini S, Pennarossa G, Gandolfi F. 2008. Recent progress in embryonic stem cell research and its application in domestic species. Reprod Domest Anim, 43(Suppl 2):193-199.

Campbell KH, McWhir J, Ritchie WA, Wilmut I. 1996. Sheep cloned by nuclear transfer from a cultured cell line. Nature, 380:64-66.

Campbell KH. 1999. Nuclear equivalence, nuclear transfer, and the cell cycle. Cloning, 1:3-15.

Cao H, Yang P, Pu Y, Sun X, Yin H, Zhang Y, Zhang Y, Li Y, Liu Y, Fang F, Zhang Z, Tao Y, Zhang X. 2012. Characterization of bovine induced pluripotent stem cells by lentiviral transduction of reprogramming factor fusion proteins. Int $\mathrm{J} \mathrm{Biol} \mathrm{Sci,}$ $8: 498-511$.
Carlson DF, Tan W, Lillico SG, Stverakova D, Proudfoot C, Christian M, Voytas DF, Long CR, Whitelaw CBA, Fahrenkrug SC. 2012. Efficient TALEN-mediated gene knockout in livestock. Proc Natl Acad Sci, 109:17382-17387.

Cervera RP, Martí-Gutiérrez N, Escorihuela E, Moreno R, Stojkovic M. 2009. Trichostatin A affects histone acetylation and gene expression in porcine somatic cell nucleus transfer embryos. Theriogenology, 72:1097-1110.

Cheng D, Guo Y, Li Z, Liu Y, Gao X, Gao Y, Cheng X, Hu J, Wang H. 2012. Porcine induced pluripotent stem cells require LIF and maintain their developmental potential in early stage of embryos. PLoS One, 7:e51778

Cheng X, Blumenthal RM. 2010. Coordinated chromatin control: structural and functional linkage of DNA and histone methylation. Biochemistry, 49:29993008.

Cho J, Bhuiyan, MMU, Shin S, Park E, Jang G, Kang S, Lee B, Hwang W. 2004. Development potential of transgenic somatic cell nuclear transfer embryos according to various factors of donor cell. $J$ Vet Med Sci, 66:1567-1573.

Choi W, Yum S, Lee S, Lee W, Lee J, Kim S, Koo O, Lee B, Jang G. 2015. Disruption of exogenous eGFP gene using RNA-guided endonuclease in bovine transgenic somatic cells. Zygote, 23:916-23.

Cibelli JB, Stice SL, Golueke PJ, Kane JJ, Jerry J, Blackwell C, Ponce de León FA, Robl JM. 1998. Cloned transgenic calves produced from nonquiescent fetal fibroblasts. Science, 280:1256-1258;

Cong L, Ran FA, Cox D, Lin S, Barretto R, Habib N, Hsu PD, Wu X, Jiang W, Marraffini LA, Zhang F. 2013. Multiplex genome engineering using CRISPR/Cas systems. Science, 339:819-823.

Deng W, Shi X, Tjian R, Lionnet T, Singer RH. 2015. CASFISH: CRISPR/Cas9-mediated in situ labeling of genomic loci in fixed cells. Proc Natl Acad Sci USA, 112:11870-11875.

Ezashi T, Yuan Y, Roberts RM. 2016. Pluripotent Stem Cells from Domesticated Mammals. Annu Rev Anim Biosci, 4:223-253.

Feng X, Cao S, Wang H, Meng C, Li J, Jiang J, Qian Y, Su L, He Q, Zhang Q. 2015. Production of transgenic dairy goat expressing human $\alpha$-lactalbumin by somatic cell nuclear transfer. Transgenic Res, 24:7385.

Gandolfi F, Pennarossa G, Maffei, S, Brevini T. 2012. Why is it so Difficult to Derive Pluripotent Stem Cells in Domestic Ungulates? Reprod Domest Anim, 47:11-17.

Gao Y, Wu H, Wang Y, Liu X, Chen L, Li Q, Cui C, Liu X, Zhang J, Zhang Y. 2017. Single Cas9 nickase induced generation of NRAMP1 knockin cattle with reduced off-target effects. Genome Biol, 18:13.

García R, Ayala PA, Perdomo SP. 2012. Epigenetic: definition, molecular basis and implications for health and human evolution. Rev Cienc Salud, 10:59-71.

Gonçalves N, Ambrósio C, Piedrahita J. 2014. Stem Cells and Regenerative Medicine in Domestic and Companion Animals: A Multispecies Perspective. 
Reprod Domest Anim, 49:2-10.

Gong G, Dai Y, Fan B, Zhu H, Wang H, Wang L, Fang C, Wan R, Liu Y, Li R, Li N. 2004. Production of transgenic blastocyst by nuclear transfer from different types of somatic cells in cattle. Sci China $C$ Life Sci, 47:183-189.

Hale CR, Zhao P, Olson S, Duff MO, Graveley BR, Wells L, Terns RM, Terns MP. 2009. RNA-Guided RNA Cleavage by a CRISPR RNA-Cas. Protein Complex Cell, 139:945-956.

He X, Ma L, He X, Si W, Zheng YM. 2016. Improved development of somatic cell cloned bovine embryos by a mammary gland epithelia cells in vitro model. $J$ Vet Sci, 17:145-152.

Hosseini SM, Dufort I, Nieminen J, Moulavi F, Ghanaei HR, Hajian M, Jafarpour F, Forouzanfar M, Gourbai H, Shahverdi AH, Nasr-Esfahani MH, Sirard MA. 2016. Epigenetic modification with trichostatin A does not correct specific errors of somatic cell nuclear transfer at the transcriptomic level; highlighting the non-random nature of oocyte-mediated reprogramming errors. BMC genomics, 4:17:16.

Houdebine LM. 2009. Production of pharmaceutical proteins by transgenic animals. Comp Immunol Microbiol Infect Dis, 32:107-121.

Hsu PD, Lander ES, Zhang F. 2014. Development and Applications of CRISPR-Cas9 for Genome Engineering. Cell, 157:1262-1278.

Hu S, Ni W, Chen C, Sai W, Hazi W, He Z, Meng R, Guo J. 2012. Comparison between the effects of Valproic acid and Trichostatin A on in vitro development of sheep somatic cell nuclear transfer embryos. J Anim Vet Adv, 11:1868-1872.

Iager AE, Ragina NP, Ross PJ, Beyhan Z, Cunniff K, Rodriguez RM, Cibelli JB. 2008. Trichostatin A improves histone acetylation in bovine somatic cell nuclear transfer early embryos. Cloning Stem Cells, 10:371-379.

Illmensee K, Hoppe PC. 1981. Nuclear transplantation in Mus musculus: developmental potential of nuclei from preimplantation embryos. Cell, 23:9-18.

Inoue K, Ogonuki N, Miki H, Hirose M, Noda S, Kim JM, Aoki F, Miyoshi H, Ogura A. 2006. Inefficient reprogramming of the hematopoietic stem cell genome following nuclear transfer. $J$ Cell Sci, 119:1985-1991.

Jansen R, Embden JD, Gaastra W, Schouls LM. 2002. Identification of genes that are associated with DNA repeats in prokaryotes. Mol Microbiol, 43:15651575.

Jeong YH, Kim YJ, Kim EY, Kim SE, Kim J, Park MJ, Lee HG, Park SP, Kang MJ. 2016. Knock-in fibroblasts and transgenic blastocysts for expression of human FGF2 in the bovine $\beta$-casein gene locus using CRISPR/Cas9 nuclease-mediated homologous recombination. Zygote, 24:442-456.

Jinek M, Chylinski K, Fonfara I, Hauer M, Doudna JA, Charpentier E. 2012. A programmable dual-RNAguided DNA endonuclease in adaptive bacterial immunity. Science, 337:816-821.

Kato Y, Tani T, Sotomaru Y, Kurokawa K, Kato J, Doguchi H, Yasue H, Tsunoda Y. 1998. Eight calves cloned from somatic cells of a single adult. Science, 282:2095-2098.

Kato Y, Tani T, Tsunoda Y. 2000. Cloning of calves from various somatic cell types of male and female adult, newborn and fetal cows. $J$ Reprod Fertil, 120:231-237.

Kishigami S, Mizutani E, Ohta H, Hikichi T, Thuan NV, Wakayama S, Bui HT, Wakayama T. 2006. Significant improvement of mouse cloning technique by treatment with Trichostatin A after somatic nuclear transfer. Biochem Biophys Res Commun, 340:183-189.

Koh S, Piedrahita JA. 2014. From "ES-like" cells to induced pluripotent stem cells: a historical perspective in domestic animals. Theriogenology, 81:103-111.

Kong Q, Ji G, Xie B, Li J, Mao J, Wang J, Liu S, Liu L, Liu Z. 2014 Telomere elongation facilitated by trichostatin a in cloned embryos and pigs by somatic cell nuclear transfer. Stem Cell Rev, 10:399-407.

Liu Z, Wan H, Wang E, Zhao X, Ding C, Zhou S, Li T, Shuai L, Feng C, Yu Y, Zhou Q, Beaujean N. 2012. Induced pluripotent stem-induced cells show better constitutive heterochromatin remodeling and developmental potential after nuclear transfer than their parental cells. Stem Cells Dev, 21:3001-3009.

Lotti SN, Polkoff KM, Rubessa M, Wheeler MB. 2017. Modification of the Genome of Domestic Animals. Anim Biotechnol, 28:198-210.

Lu D, Liu S, Ding F, Wang H, Li J, Li L, Dai Y, Lib N. 2016. Large-scale production of functional human lysozyme from marker-free transgenic cloned cows. Sci Rep, 6:22947.

Luo C, Lu F, Wang X, Wang Z, Li X, Gong F, Jiang J, Liu Q, Shi D. 2013. Treatment of donor cells with trichostatin A improves in vitro development and reprogramming of buffalo (Bubalus bubalis) nucleus transfer embryos. Theriogenology, 80:878-886.

Matoba S, Liu Y, Lu F, Iwabuchi KA, Shen L, Inoue A, Zhang Y. 2014. Embryonic development following somatic cell nuclear transfer impeded by persisting histone methylation. Cell, 159:884-895.

McGrath J, Solter D. 1983. Nuclear transplantation in the mouse embryo by microsurgery and cell fusion. Science, 220:1300-1302

Menchaca A, Anegon I, Whitelaw CBA, Baldassarre H, Crispo M. 2016. New insights and current tools for genetically engineered (GE) sheep and goats. Theriogenology, 86:160-169.

Miyoshi K, Mori H, Mizobe Y, Akasaka E, Ozawa A, Yoshida M, Sato M. 2010. Valproic acid enhances in vitro development and Oct-3/4 expression of miniature pig somatic cell nuclear transfer embryos. Cel Reprogram, 12:67-74.

Mojica FJ, Diez-Villasenor C, Soria E, Juez G. 2000. Biological significance of a family of regularly spaced repeats in the genomes of Archaea, Bacteria and mitochondria. Mol Microbiol, 36:244-246.

Monzani PS, Bressan FF, Mesquita LG, Sangalli JR, Meirelles FV. 2011. Casein gene expression by in vitro cultured bovine mammary epithelial cells derived from developing mammary glands. Genet Mol Res GMR, 10:604-614.

Monzani PS, Sangalli JR, De Bem THC, Bressan FF, 
Fantinato-Neto P, Pimentel JRV, Birgel-Junior EH, Fontes AM, Covas DT, Meirelles FV. 2013. Breeding of transgenic cattle for human coagulation factor IX by a combination of lentiviral system and cloning. Genet Mol Res, 12:3675-3688.

Muñoz M, Rodríguez A, De Frutos C, Caamaño JN, Díez C, Facal N, Gómez E. 2008. Conventional pluripotency markers are unspecific for bovine embryonic-derived cell-lines. Theriogenology, 69:11591164

Murakami M, Fahrudin M, Varisanga MD, Suzuki T. 1999. Fluorescence expression by bovine embryos after pronuclear microinjection with the EGFP gene. $J$ Vet Med Sci, 61:843-847.

Ni W, Qiao J, Hu S, Zhao X, Regouski M, Yang M, Polejaeva IA ,Chen C. 2014. Efficient gene knockout in goats using CRISPR/Cas9 system. PLoS ONE 9(9): e106718.

Niu D, Wei H-J, Lin L, George H, Wang T, Lee I-H, Zhao H-Y, Wang Y, Kan Y, Shrock E, Lesha E, Wang G, Luo Y, Qing Y, Jiao D, Zhao H, Zhou X, Wang S, Wei H, Güell M, Church GM, Yang L. 2017. Inactivation of porcine endogenous retrovirus in pigs using CRISPR-Cas9. Science, 357:1303-1307.

Nowak-Imialek M, Kues W, Carnwath JW, Niemann H. 2011. Pluripotent stem cells and reprogrammed cells in farm animals. Microsc Microanal, 17:474-497.

Park K-E, Telugu BPVL. 2014. Role of stem cells in large animal genetic engineering in the TALENs/CRISPR era. Reprod FertiL Dev, 26: 65-73.

Peng R, Lin G, Li J. 2016. Potential pitfalls of CRISPR/Cas9-mediated genome editing. FEBS $J$, 283:1218-1231.

Petersen B, Niemann H. 2015. Molecular scissors and their application in genetically modified farm animals. Transgenic Res, 24:381-396.

Picanço-Castro V, Russo-Carbolante E, Reis LCJ, Fraga AM, de Magalhães DAR, Orellana MD, Panepucci RA, Pereira LV, Covas DT. 2011. Pluripotent reprogramming of fibroblasts by lentiviral mediated insertion of SOX2, C-MYC, and TCL-1A. Stem Cells Dev, 20:169-180.

Prather RS, Barnes FL, Sims MM, Robl JM, Eyestone WH, and First NL. 1987. Nuclear transplantation in the bovine embryo: assessment of donor nuclei and recipient oocyte. Biol Reprod, 37:859866.

Puri MC, Nagy A. 2012. Concise review: Embryonic stem cells versus induced pluripotent stem cells: the game is on. Stem Cells, 30:10-14.

Reik W, Dean W, Walter J. 2001. Epigenetic reprogramming in mammalian development. Science, 293:1089-1093.

Rémy S, Tesson L, Ménoret S, Usal C, Scharenberg AM, Anegon I. 2010. Zinc-finger nucleases: a powerful tool for genetic engineering of animals. Transgenic Res, 19:363-371.

Ren Z, Wang Y, Ren Y, Zhang Z, Gu W, Wu Z, Chen L, Mou L, Li R, Yang H, Daib Y. 2017. Enhancement of porcine intramuscular fat content by overexpression of the cytosolic form of phosphoenolpyruvate carboxykinase in skeletal muscle. Sci Rep, 7:43746.

Rülicke TH, Montagutelli X, Pintado B, Thon R, Hedrich HJ. 2007. FELASA guidelines for the production and nomenclature of transgenic rodents. $L a b$ Anim, 41:301-311.

Salozhin SV, Prokhorchuk EB, Georgiev GP. 2005. Methylation of DNA-one of the major epigenetic markers. Biochemistry Mosc, 70:525-532.

Sangalli JR, Chiaratti MR, De Bem THC, de Araújo RR, Bressan FF, Sampaio RV, Perecin F, Smith LC, King WA, Meirelles FV. 2014. Development to term of cloned cattle derived from donor cells treated with valproic Acid. PLoS One, 9:e101022.

Sangalli JR, De Bem THC, Perecin F, Chiaratti MR, Oliveira L de J, de Araújo RR, Valim Pimentel JR, Smith LC, Meirelles FV. 2012. Treatment of nucleardonor cells or cloned zygotes with chromatin-modifying agents increases histone acetylation but does not improve full-term development of cloned cattle. Cell Reprogram, 14:235-247.

Schmittwolf C, Kirchhof N, Jauch A, Dürr M, Harder F, Zenke M, Müller AM. 2005. In vivo haematopoietic activity is induced in neurosphere cells by chromatin-modifying agents. EMBO J, 24:554-566.

Schnieke AE, Kind AJ, Ritchie WA, Mycock K, Scott AR, Ritchie M, Wilmut I, Colman A, Campbell KH. 1997. Human factor IX transgenic sheep produced by transfer of nuclei from transfected fetal fibroblasts. Science, 278:2130-2133.

Shi LH, Ai JS, Ouyang YC, Huang JC, Lei ZL, Wang Q, Yin S, Han ZM, Sun QY, Chen DY. 2008. Trichostatin A and nuclear reprogramming of cloned rabbit embryos. J Anim Sci, 86:1106-1113.

Shi W, Hoeflich A, Flaswinkel H, Stojkovic M, Wolf E, Zakhartchenko V. 2003. Induction of a senescentlike phenotype does not confer the ability of bovine immortal cells to support the development of nuclear transfer embryos. Biol Reprod, 69:301-309.

Smith LC, Suzuki J, Goff AK, Filion F, Therrien J, Murphy BD, Kohan-Ghadr HR, Lefebvre R, Brisville AC, Buczinski S, G Fecteau, Perecin F, Meirelles FV. 2012. Developmental and epigenetic anomalies in cloned cattle. Reprod Domest Anim, 47(Suppl 4):107-114.

Smith LC, Therrien J, Filion F, Bressan F, Meirelles FV. 2015. Epigenetic consequences of artificial reproductive technologies to the bovine imprinted genes SNRPN, H19/IGF2, and IGF2R. Front Genet, 6:58.

Song Y, Hai T, Wang Y, Guo R, Li W, Wang L, Zhou Q. 2014. Epigenetic reprogramming, gene expression and in vitro development of porcine SCNT embryos are significantly improved by a histone deacetylase inhibitor-m-carboxycinnamic acid bishydroxamide (CBHA). Protein Cell, 5:382-393.

Sung LY, Gao S, Shen H, Yu H, Song Y, Smith SL, Chang CC, Inoue K, Kuo L, Lian J, Li A, Tian XC, Tuck DP, Weissman SM, Yang X, Cheng T. 2006. Differentiated cells are more efficient than adult stem cells for cloning by somatic cell nuclear transfer Nature Genetics, 38:1323-1328.

Suzuki J, Therrien J, Filion F, Lefebvre R, Goff AK, 
Smith LC. 2009. In vitro culture and somatic cell nuclear transfer affect imprinting of SNRPN gene in pre- and post-implantation stages of development in cattle. BMC Dev Biol, 9:9.

Takahashi K, Yamanaka S. 2006. Induction of pluripotent stem cells from mouse embryonic and adult fibroblast cultures by defined factors. Cell, 126:663-676.

Takahashi K, Tanabe K, Ohnuki M, Narita M, Ichisaka T, Tomoda K, Yamanaka S. 2007. Induction of pluripotent stem cells from adult human fibroblasts by defined factors. Cell, 131:861-872.

Wang LJ, Zhang H, Wang YS, Xu WB, Xiong XR, Li YY, Su JM., Hua S, Zhang Y. 2011. Scriptaid improves in vitro development and nuclear reprogramming of somatic cell nuclear transfer bovine embryos. Cell Reprogram, 13:431-439.

Wells DN, Misica PM, Tervit HR. 1999. Production of cloned calves following nuclear transfer with cultured adult mural granulosa cells. Biol Reprod, 60:996-1005.

Whyte JJ, Zhao J, Wells KD, Samuel MS, Whitworth KM, Walters EM, Laughlin MH, Prather, RS. 2011. Gene targeting with zinc finger nucleases to produce cloned eGFP knockout pigs . Mol Reprod Dev 78(1): 2-2

Willadsen SM. 1986. Nuclear transplantation in sheep embryos. Nature, 320:63-65.

Wilmut I, Bai Y, Taylor J. 2015. Somatic cell nuclear transfer: origins, the present position and future opportunities. Philos Trans R Soc Lond B Biol Sci, 370: 20140366

Wilmut I, Beaujean N, de Sousa PA, Dinnyes A, King TJ, Paterson LA, Wells DN, Young LE. 2002. Somatic cell nuclear transfer. Nature, 419:583-587.

Wilmut I, Schnieke AE, McWhir J, Kind AJ, Campbell KH. 1997. Viable offspring derived from fetal and adult mammalian cells. Nature, 385:810-813.

Wu H, Wang Y, Zhang Y, Yang M, Lv J, Liu J, Zhang Y. 2015. TALE nickase-mediated SP110 knockin endows cattle with increased resistance to tuberculosis. Proc Natl Acad Sci USA, 112:1530-1539.

Wu J, Vilarino M, Suzuki K, Okamura D, Bogliotti
YS, Park I, Rowe J, McNabb B, Ross PJ, Belmonte JCI. 2017. CRISPR-Cas9 mediated one-step disabling of pancreatogenesis in pigs. Sci Rep, 7:10487.

Xu W, Wang Y, Li Y, Wang L, Xiong X, Su J, Zhang Y. 2012. Valproic acid improves the in vitro development competence of bovine somatic cell nuclear transfer embryos. Cell Reprog, 14:138-145.

Yang X, Smith SL, Tian XC, Lewin HA, Renard JP, Wakayama T. 2007. Nuclear reprogramming of cloned embryos and its implications for therapeutic cloning. Nat Genet, 39:295-302.

Yu J, Vodyanik MA, Smuga-Otto K, AntosiewiczBourget J, Frane JL, Tian S, Nie J, Jonsdottir GA, Ruotti V, Stewart R, Slukvin II, Thomson JA. 2007. Induced pluripotent stem cell lines derived from human somatic cells. Science, 318:1917-1920.

Zakartchenko V, Alberio R, Stojkovic M, Prelle K, Schernthaner W, Stojkovic $\mathbf{P}$, Wenigerkind $\mathbf{H}$, Wanke R, Düchler M, Steinborn R, Mueller M, Brem G, Wolf E. 1999. Adult cloning in cattle: potential of nuclei from a permanent cell line and from primary cultures. Mol Reprod Dev, 54: 264-272.

Zhan K, Lin M, Liu M, Sui Y, Babekir HM, Zhao G. 2017. Three-dimensional culture system can induce expression of casein in immortalized bovine mammary epithelial cells. Animal science Journal, 88:817-825

Zhang L, Huang Y, Wu Y, Si J, Huang Y, Jiang Q, Lan G, Guo Y, Jiang H. 2017. Scriptaid upregulates expression of development-related genes, inhibits apoptosis, and improves the development of somatic cell nuclear transfer mini-pig embryos. Cel Reprog, 19:19-26.

Zhao L, Wang Z, Zhang J, Yang J, Gao X, Wu B, Zhao G, Bao S, Hu S, Liu P, Li X. 2017. Characterization of the single-cell derived bovine induced pluripotent stem cells. Tissue cell, 49:521-527.

Zhou S, Ding C, Zhao X, Wang E, Dai X, Liu L, Li W, Liu Z, Wan H, Feng C, Tang Hai, Liu Wang, Qi Zhou. 2010. Successful generation of cloned mice using nuclear transfer from induced pluripotent stem cells. Cell Res, 20:850-853. 